\title{
INTERVENSI PADA POPULASI RISIKO TINGGI SKIZOFRENIA, PERLUKAH?
}

\author{
Putri AN*, Yuniar S** \\ * Dokter Umum, Peserta PPDS I Prodi Psikiatri Departemen/SMF Ilmu Kedokteran Jiwa FK UNAIR/RSUD dr. Soetomo Surabaya \\ **Dokter Spesialis Kedokteran Jiwa/Psikiater, Psikiater Konsultan, Staf Pengajar Departemen/SMF Ilmu Kedokteran Jiwa FK UNAIR/RSUD dr. Soetomo \\ Surabaya
}

\begin{abstract}
ABSTRAK
Skizofrenia adalah gangguan jiwa dengan manifestasi kondisi psikotik yang berat dan persisten serta bersifat kronis dimana sebagian besar orang dengan Skizofrenia terlambat dibawa ke fasilitas kesehatan. Kebanyakan masyarakat tidak mengetahui gejala awal yang dialami oleh seseorang meskipun orang tersebut mempunyai riwayat keluarga dengan Skizofrenia. Terdapat beberapa strategi dan intervensi sebagai upaya pengobatan pada gejala awal Skizofrenia sehingga diharapkan dapat mengurangi angka disabilitas. Beberapa peneliti mulai melakukan intervensi pada populasi risiko tinggi dengan cara pemberian omega 3, terapi supportif dan terapi keluarga. Peneliti juga mempertimbangkan pemberian farmakologi antipsikotik atipikal dosis rendah sebagai pencegahan Skizofrenia tetapi hal ini masih menjadi perdebatan.
\end{abstract}

Kata kunci: Skizofrenia, populasi risiko tinggi, intervensi awal

Corresponding author: Ayu Nuzulia Putri, dr.

Dep/SMF Kedokteran Jiwa FK UNAIR/RSUD Dr.Soetomo Surabaya HP: 085733900086 | email: dr.nuzulia@gmail.com 


\section{PENDAHULUAN}

Psikotik merupakan istilah yang digunakan untuk menjelaskan suatu kondisi gangguan jiwa berat yang secara khas ditandai dengan adanya hendaya dalam menilai realitas dan menganggu kehidupan dan pekerjaan seharihari. Jenis psikotik yang paling sering terjadi adalah Skizofrenia, termasuk sepuluh besar penyakit dan menempati tingkat pertama pada gangguan psikiatri yang menyebabkan disabilitas (Fatemi, 2008).

Prevalensi dari Skizofrenia secara keseluruhan diperkirakan $1 \%$, artinya satu orang diantara 100 orang akan mengalami Skizofrenia dalam hidupnya. Di Amerika Serikat, $0.05 \%$ dari total populasi dirawat dan di Indonesia mencapai tujuh per 1000 penduduk tiap tahunnya (Riskerdas, 2018; Saddock et al., 2015). Di Amerika, estimasi dana yang dihabiskan untuk biaya pengobatan dan biaya hidup yang terkait dengan gangguan jiwa psikotik kurang lebih menghabiskan 3,8 juta dolar per tahun dan hal ini tidak berbeda jauh dengan di Inggris yang menghabiskan 4 juta poundsterling tiap tahunnya (MorenoKutser et al., Murray et al., 2018). Konsep terkini dari Skizofrenia dihipotesiskan bahwa penyakit ini berkembang dari risiko tinggi tanpa gejala (fase premorbid) berkembang menjadi fase prodromal kemudian fase psikotik sehingga muncul pertanyaan apakah pemberian anti psikotik dapat digunakan sebagai "profilaksis" untuk mencegah terjadinya Skizofrenia (Stahl, 2013).

\section{PRODROMAL PSIKOTIK}

\section{Definisi}

Istilah prodromal berasal dari kata "prodromos" berasal dari bahasa Yunani yang artinya pendahulu dari peristiwa. Dalam pengobatan klinis, prodromal mengacu pada gejala awal dan tanda-tanda yang mendahului manifestasi dari penyakit (Yung \& Philips, 2004).

Prodromal didefinisikan sebagai keadaan awal atau prepsikotik yang mewakili penyimpangan perilaku dan pengalaman individu yang berbeda dari biasanya (Yung \& McGory, 1996). Oleh karena itu prodromal dikategorikan sebagai proses menjelang fase full-blown dari penyakit (Tully \& McGlashan, 2006).

\section{Gejala}

Deteksi awal fase premorbid merupakan hal yang sulit dilakukan. Telah diakui selama bertahun tahun beberapa individu yang mengalami psikotik dan berkembang menjadi Skizofrenia memiliki defisit sosial, perilaku, penurunan fungsi kognitif serta berbagai masalah sosial (Tully \& McGlashan, 2006).

\section{Etiologi}

Faktor penyebab gangguan psikotik dipengaruhi oleh berbagai faktor yang saling mempengaruhi, antara lain faktor genetik, faktor biokimia, faktor neuroanatomi dan faktor psikososial. Adapula faktor genetik mempunyai peranan yang paling besar pada penderita Skizofrenia. Jika salah satu orang tua mengalami Skizofrenia, prevalensi seseorang yang mengalami gangguan yang sama mencapai $12 \%$. Jika kedua orang tuanya mengalami Skizofrenia maka risiko seseorang untuk mengalami

Tabel 1. Gambaran Prodromal Skizofrenia

\begin{tabular}{ll}
\hline Gambaran Prodromal & Gejala yang Tampak \\
\hline Gejala neurotik & Kecemasan, gelisah, tidak tenang, mudah tersinggung \\
Gejala terkait mood & Depresi, anhedonia, rasa bersalah, keinginan bunuh diri, mood yang labil \\
Perubahan sikap & Apatis (kehilangan dorongan), kehilangan ketertarikan, mudah lelah (berkurangnya \\
& energi) \\
Perubahan kognitif & Gangguan perhatian dan konsentrasi, sering melamun, pikiran buntu, penurunan \\
& kemampuan abstrak \\
Gangguan fisik & Keluhan somatik, penurunan berat badan, kurangnya nafsu makan, gangguan tidur \\
Gangguan gejala psikotik & Gangguan persepsi, perubahan penilaian diri, perubahan afek dan perubahan \\
& psikomotor \\
Gejala lain & Fenomena obsesif kompulsif, fenomena disosiatif, peningkatan sensitivitas \\
& interpersonal \\
Perubahan perilaku & Kemunduran fungsi peran, penarikan sosial, impulsif, perilaku aneh, agresif \\
\hline
\end{tabular}


gangguan yang sama meningkat menjadi $40 \%$. Prevalensi Skizofrenia adalah $47 \%$ pada kembar monozigot, $12 \%$ pada kembar dizigotik dan $8 \%$ pada saudara kandung yang tidak kembar (Saddock et al., 2015, Semple \& Smyth 2013).

\section{Populasi Risiko Tinggi Skizofrenia}

\section{Definisi Populasi Risiko Tinggi Skizofrenia}

Populasi risiko tinggi adalah populasi yang mempunyai faktor yang berkorelasi risiko dibandingkan mekanisme penyebab yang diketahui, bahkan secara statistik dapat "memprediksi" psikosis di kemudian hari (F. Schultze-Lutter et al., 2015).

\section{Faktor Genetik}

Bukti atas peran faktor genetik dalam gangguan psikotik berasal dari tingkat kesesuaian yang tinggi dalam kerabat biologis individu yang terkena dampak, termasuk pada mereka yang dipelihara secara terpisah. Misalnya, memiliki kerabat tingkat pertama dengan Skizofrenia meningkatkan sepuluh kali lipat, yang membuat riwayat keluarga psikosis menjadi salah satu faktor risiko terkuat (Kendler, 1993).

\section{Fungsi Sosial}

Fungsi sosial adalah gangguan yang diketahui pada mereka yang berisiko mengalami skizofrenia (APA, 2013). Kesulitan sosial dimulai sejak anak usia dan semakin menurun pada periode menjelang episode pertama. Bahkan gambaran seperti kesulitan menyimpulkan niat orang lain (Theory of Mind) telah menjadi bagian dari kriteria terkait untuk diagnosis skizofrenia selama beberapa waktu (Tarbox et al., 2008).

\section{Neuroimaging}

Perubahan struktur otak pada populasi risiko tinggi mirip tetapi tidak separah skizofrenia (Brent BK et al., 2013). Kelompok risiko tinggi menunjukkan volume substansia grisea yang lebih kecil dan penipisan kortikal pada prefrontal, temporal lateral (terutama girus temporalis superior) dan pada tingkat lebih rendah, korteks parietal (Thermenos et al, 2013). Substansia grisea korteks prefrontal yang lebih sedikit dikaitkan dengan gangguan fungsi eksekutif dan keparahan gejala yang lebih besar pada individu dengan risiko klinis tinggi sedangkan substansia grisea temporal superior dari girus superior yang lebih kecil telah dikaitkan dengan defisit semantik (Brent BK et al, 2013).

\section{Inflamasi}

Dalam beberapa tahun terakhir, banyak penelitian hubungan proses inflamasi dengan gangguan neuropsikiatri termasuk psikosis (Anderson, 2013). Pada pasien dengan Skizofrenia terjadi perubahan tingkat inflamasi, stres oksidatif dan metabolisme (Thompson KN, 2007).

\section{Stress, Stress Sensitivity, dan Cortisol}

Model diatesis/kerentanan-stres yang diterima secara umum menunjukkan bahwa individu yang berisiko, atau menderita gangguan psikotik lebih rentan terhadap stres dan dapat memicu episode psikotik (Anderson et al, 2013). Tinjauan literatur menunjukkan adanya hubungan stres pada populasi risiko tinggi dengan angka terjadinya Skizofrenia (Steullar, 2014). Terdapat banyak bukti bahwa trauma masa kecil, termasuk pelecehan fisik, pelecehan seksual, dan intimidasi dapat menjadi stresor langsung (Schlosser, 2013). Individu dengan risiko tinggi Skizofrenia cenderung mengalami peristiwa yang lebih subyektif daripada individu non-risiko tinggi, dimana periode prodromal mungkin merupakan fase stres subyektif yang meningkat (Throtman HD, 2014).

\section{Risiko Tinggi Klinis (Clinical High Risk/CHR) dari Psikosis}

Terdapat dua pendekatan komplementer untuk mengklasifikasikan status CHR psikosis yakni risiko sangat tinggi (Ultra High Risk/UHR) dan kriteria gejala dasar (Fusar Poli, 2012). Selain kriteria UHR, terdapat kriteria gejala psikotik yang samar (Attenuated Psychotic Symptom/APS), kriteria Brief Limited Intermittent Psychotic Symptom (BLIPS) dan kriteria Genetic Risk and Functional Decline (GRFD), yang awalnya dikembangkan dengan tujuan untuk mendeteksi terjadinya psikosis (Philips et al, 2000).

\section{Kriteria Risiko Tinggi Berdasarkan European Psychiatric Organization (EPA)}

EPA mempertimbangkan tiga kriteria CHR yang seharusnya dapat digunakan pada deteksi awal dari psikosis atau disebabkan oleh keluhan somatik yang menunjukkan setidaknya satu dari gejala psikotik yang samar, misalnya (1) isi pikiran tidak biasa atau ide delusi atau idea of reference, (2) persepsi atau halusinasi dengan insight, (3) perkataan yang disorganisasi yang masih komprehensif dan respon pada struktur sebuah interview yang termasuk kriteria Structured Interview for Psychosis Risk Syndrome (SIPS) atau Comprehensive Assessment of At Risk States (CAARMS) (Schultze Lutter et al, 2012). 
Tabel 2. Kriteria Risiko Tinggi (UHR)

Pendekatan Gejala

A. Adanya satu gejala psikotik yang muncul singkat (BLIPS)

Halusinasi

Delusi

Kekacauan proses berpikir

B. Adanya satu gejala negatif (APS)

Idea of reference

Keyakinan atau pemikiran ghaib

Ide paranoid

Pengalaman persepsi yang tidak biasa

Berpikir dan berbicara aneh

Pendekatan kondisi

C. Terdapat riwayat genetik (riwayat keluarga psikosis; gangguan kepribadian skizotipal) dengan penurunan fungsi psikososial yang signifikan

Sumber: (Tully \& McGlashan, 2006) Prodrome of Schizophrenia

\section{Intervensi Pada Populasi Risiko Tinggi Skizofrenia}

Penelitian metaanalisis terbaru menemukan dampak gabungan yang signifikan pada pengurangan transisi dari populasi resiko tinggi menjadi psikosis (Van der Gaag, 2016). Intervensi pada populasi risiko tinggi mencegah trasnsisi menjadi psikosis rata-rata 64\% pada enam bulan, $54-56 \%$ pada satu tahun dan $35-42 \%$ pada $2-4$ tahun setelah mendapat intervensi (Van der Gaag, 2016).

\section{Non Farmakologi}

\section{Strategi Kognitif dan Kognitif Perilaku (CBT)}

CBT dapat dilakukan untuk mengurangi kecemasan dan depresi, dua gejala yang sering muncul pada orang dengan Skizofrenia (Wood SW, 2009). CBT memiliki manfaat potensial untuk mengatasi gejala dan berfungsi baik secara spesifik dan non spesifik pada populasi risiko psikosis.

\section{Terapi Keluarga}

Pilihan perawatan logis yang digunakan pada risiko psikosis. Pada terapi keluarga menggunakan format satu grup keluarga atau banyak keluarga sebagai buffer dari dampak stressor lingkungan (Hooley, 2005). Pada terapi keluarga berfokus pada psikoedukasi, membangun ketrampilan komunikasi dan pemecahan masalah. Psikoedukasi intensif dan pertemuan kelompok dilakukan dua mingguan selama 1-2 tahun (Miklowitz, 2014).

\section{Remediasi / Peningkatan Kognitif}

Beberapa studi penelitian dilakukan pada orang dengan populasi risiko tinggi psikosis yang mengalami kesulitan kognitif. Remediasi kognitif secara komputerisasi seperti Cogpack, Lumosity, The Brain Fitness Program, SocialVille, atau PositScience (Wykes, 2011). Programprogram ini menyediakan pelatihan dalam bidang kognitif seperti perhatian, kecepatan pemrosesan fungsi eksekutif, pembelajaran dan memori dan persepsi sosial. Individu biasanya menyelesaikan sesi pelatihan beberapa kali per minggu.

\section{Pelatihan Ketrampilan Sosial (Social-skill Training)}

Dilakukan secara individu atau kelompok yang menargetkan kognisi dan fungsi, termasuk persepsi sosial, ketrampilan sosial dan ketrampilan untuk kesejahteraan hidup (Koutsouleris, 2012). Dukungan pada pekerjaan dan pendidikan secara langsung membantu individu dalam menemukan dan mempertahankan pekerjaan dan pendidikan yang telah dijalaninya.

\section{Terapi Suportif}

Terapi ini untuk memberikan dukungan dan edukasi bagi keluarga, dapat juga diberikan pada krisis intervensi psikotik misalkan dukungan emosional dan sosial untuk menghadapi stres sehari-hari atau pemecahan masalah dam manajemen stress (Woods SW, 2009). 


\section{Farmakologi}

Beberapa negara telah memulai reformasi substansial layanan kesehatan mental untuk meningkatkan intervensi awal atau mengalihkan dana ke intervensi baru (Birchwood, 2013). Pemberian farmakologi termasuk suplemen gizi pada populasi risiko psikosis adalah Risperidon 0,5-2 mg, Olanzapin 5-15 mg, Asam lemak omega-3 1,2 g). Pertimbangan pemberian antipsikotik pada populasi risiko psikosis harus memperhatikan efek samping dari obat antipsikotik seperti peningkatan berat badan, disfungsi seksual, dan efek samping ekstrapiramidal bisa sangat besar, menimbulkan risiko serius bagi kesehatan dan kesejahteraan, dan mungkin sangat tidak dapat ditoleransi untuk remaja dan dewasa muda (Francey, 2010).

\section{RINGKASAN}

Ide intervensi untuk pencegahan gangguan psikotik telah dipertimbangkan dalam dua dekade terakhir. Karakteristik prodromal merupakan keadaan klinis yang berisiko tinggi dan memberikan tempat intervensi untuk memperpanjang waktu transisi menjadi psikosis atau mencegah perburukan dari psikosis menjadi Skizofrenia.

Beberapa intervensi yang mempunyai risiko rendah seperti psikososial, suportif sampai risiko yang lebih tinggi dengan menggunakan psikofarmakologi masih dalam tahap evaluasi. Semua intervensi yang disebutkan masih memerlukan uji etik, kelayakan, efektifitas dan tolerabilitas untuk penderita.

\section{DAFTAR PUSTAKA}

1. Carrión, R. E., Correll, C. U., Auther, A. M., \& Cornblatt, B. A. (2017). A severity-based clinical staging model for the psychosis prodrome: Longitudinal findings from the New York recognition and prevention program. Schizophrenia Bulletin, 43(1), 64-74. https://doi.org/10.1093/schbul/sbw155

2. Cornblatt, B. A., Carrión, R. E., Auther, A., McLaughlin, D., Olsen, R. H., John, M., \& Correll, C. U. (2015). Psychosis prevention: A modified clinical high risk perspective from the recognition and prevention (RAP) Program. American Journal of Psychiatry, 172(10), 986-994. https://doi.org/10.1176/ appi.ajp.2015.13121686

3. Fusar-Poli, P. (2017). The clinical high-risk state for psychosis (CHR-P), Version II. Schizophrenia Bulletin, 43(1), 44-47. https://doi.org/10.1093/schbul/ sbw158

4. Fusar-Poli, P., Yung, A. R., McGorry, P., \& Van Os, J. (2014). Lessons learned from the psychosis high-risk state: Towards a general staging model of prodromal intervention. Psychological Medicine, 44(1), 17 -24. https://doi.org/10.1017/S0033291713000184
5. Iyer, S., Jordan, G., Macdonald, K., Joober, R., \& Malla, A. (2015). Early intervention for psychosis: A Canadian perspective. Journal of Nervous and Mental Disease, 203(5), 356-364. https:// doi.org/10.1097/NMD.0000000000000288

6. Joa, I., Gisselgård, J., Brønnick, K., McGlashan, T., \& Johannessen, J. O. (2015). Primary prevention of psychosis through interventions in the symptomatic prodromal phase, a pragmatic Norwegian ultra high risk study. BMC Psychiatry, 15(1), 1-9. https:// doi.org/10.1186/s12888-015-0470-5

7. Kahn, R. S., \& Sommer, I. E. (2015). The neurobiology and treatment of first-episode schizophrenia. Molecular Psychiatry, 20(1), 84-97. https:// doi.org/10.1038/mp.2014.66

8. Kirkbride, J. B., Hameed, Y., Ankireddypalli, G., Ioannidis, K., Crane, C. M., Nasir, M., Jones, P. B. (2017). The epidemiology of first-episode psychosis in early intervention in psychosis services: Findings from the sosial epidemiology of psychoses in east Anglia [SEPEA] Study. American Journal of Psychiatry, 174(2), 143-153. https://doi.org/10.1176/ appi.ajp.2016.16010103

9. Kurachi, M., Takahashi, T., Sumiyoshi, T., Uehara, T., \& Suzuki, M. (2018). Early intervention and a direction of novel therapeutics for the improvement of functional outcomes in schizophrenia: A selective review. Frontiers in Psychiatry, 9(FEB), 1-11. https://doi.org/10.3389/fpsyt.2018.00039

10. Langer, Á. I., Schmidt, C., Mayol, R., Díaz, M., Lecaros, J., Krogh, E., Gaspar, P. A. (2017). The effect of a mindfulness-based intervention in cognitive functions and psychological well-being applied as an early intervention in schizophrenia and highrisk mental state in a Chilean sample: Study protocol for a randomized controlled trial. Trials, 18(1), 1-9. https://doi.org/10.1186/s13063-017-1967-7

11. Laurens, K. R., \& Cullen, A. E. (2016). Toward earlier identification and preventative intervention in schizophrenia: evidence from the London Child Health and Development Study. Sosial Psychiatry and Psychiatric Epidemiology, 51(4), 475-491. https:// doi.org/10.1007/s00127-015-1151-x

12. Lieberman, J. A., Girgis, R. R., Brucato, G., Moore, H., Provenzano, F., Kegeles, L., Small, S. A. (2018). Hippocampal dysfunction in the pathophysiology of schizophrenia: a selective review and hypothesis for early detection and intervention. Molecular Psychiatry, 23(8), 1764-1772. https://doi.org/10.1038/ $\underline{m p .2017 .249}$

13. McGorry, P. D. (2015). Early intervention in psychosis: Obvious, effective, overdue. Journal of Nervous and Mental Disease, 203(5), 310-318. https:// doi.org/10.1097/NMD.0000000000000284

14. Riskesdas. (2018). Hasil Utama Riskesdas 2018. http:// www.depkes.go.id/resources/download/infoterkini/ materi rakorpop 2018/Hasil\%20Riskesdas\% 202018.

15. Saddock, B.J., Virginia. A.S. \& Ruiz. P. (2018). Kaplan and Sadock's Comprehensive Textbook of Psychiatry $10^{\text {th }}$ edition. Schizophrenia pages 225-230. 
16. Schmidt, S. J., Schultze-Lutter, F., Schimmelmann, B. G., Maric, N. P., Salokangas, R. K. R., Riecher-Rössler, A., ... Ruhrmann, S. (2015). EPA guidance on the early intervention in clinical high risk states of psychoses. European Psychiatry, 30(3), 388-404. https:// doi.org/10.1016/j.eurpsy.2015.01.013

17. Schultze-Lutter, F., Michel, C., Schmidt, S. J., Schimmelmann, B. G., Maric, N. P., Salokangas, R. K. R., ... Klosterkötter, J. (2015). EPA guidance on the early detection of clinical high risk states of psychoses. European Psychiatry, 30(3), 405-416. https:// doi.org/10.1016/j.eurpsy.2015.01.010

18. Seidman, L. J., \& Nordentoft, M. (2015). New Targets for Prevention of Schizophrenia: Is It Time for Interventions in the Premorbid Phase? Schizophrenia Bulletin, 41(4), 795-800. https://doi.org/10.1093/schbul/sbv050

19. Sommer, I. E., Bearden, C. E., Van Dellen, E., Breetvelt, E. J., Duijff, S. N., Maijer, K., Vorstman, J. A. S. (2016). Early interventions in risk groups for schizophrenia: What are we waiting for? Npj Schizophrenia, 2 (December 2015). https://doi.org/10.1038/ npjschz.2016.3

20. Stahl, S.M. (2018). Stahl's Essential Psychopharmacology Neuroscientific Basis and Practical Application Fourth Edition. Psychosis and Schizophrenia Pages 114-119. 